\title{
Out of Amazonia: Late-Holocene climate change and the Tupi-Guarani trans-continental expansion
}

\author{
José Iriarte,' Richard J Smith, ${ }^{2}$ Jonas Gregorio de Souza,' \\ Francis Edward Mayle, ${ }^{2}$ Bronwen S Whitney, ${ }^{3}$ \\ Macarena Lucia Cárdenas, ${ }^{2}$ Joy Singarayer, ${ }^{2}$ \\ John F Carson, ${ }^{2}$ Shovonlal Roy ${ }^{2}$ and Paul Valdes ${ }^{4}$
}

\begin{abstract}
The late-Holocene expansion of the Tupi-Guarani languages from southern Amazonia to SE South America constitutes one of the largest expansions of any linguistic family in the world, spanning $\sim 4000 \mathrm{~km}$ between latitudes $0^{\circ} \mathrm{S}$ and $35^{\circ} \mathrm{S}$ at about $2.5 \mathrm{k} \mathrm{cal}$. $\mathrm{yr} \mathrm{BP}$. However, the underlying reasons for this expansion are a matter of debate. Here, we compare continental-scale palaeoecological, palaeoclimate and archaeological datasets, to examine the role of climate change in facilitating the expansion of this forest-farming culture. Because this expansion lies within the path of the South American Low-Level Jet, the key mechanism for moisture transport across lowland South America, we were able to explore the relationship between climate change, forest expansion and the Tupi-Guarani. Our data synthesis shows broad synchrony between late-Holocene increasing precipitation and southerly expansion of both tropical forest and Guarani archaeological sites - the southernmost branch of the Tupi-Guarani. We conclude that climate change likely facilitated the agricultural expansion of the Guarani forest-farming culture by increasing the area of forested landscape that they could exploit, showing a prime example of ecological opportunism.
\end{abstract}

\section{Keywords}

Amazonia, human ecology, language expansion, late-Holocene climate change, palaeoclimate, Tupi-Guarani

Received II March 2016; revised manuscript accepted 7 October 2016

\section{Introduction}

The expansion of farmers and their languages is arguably one of the most important processes that took place during Holocene human history (Ammerman and Cavalli-Sforza, 2014; Anthony, 2009; Bellwood and Renfrew, 2002; Kirch, 2000). This process brought significant changes in technologies and social and political structures, as well as novel landscape management practices to the new regions that were colonised. Across the globe, several cultural expansions have been associated with climate change, whereby climate exerted a control on the extent of landscapes favoured by particular cultural groups (e.g. Büntgen et al., 2016; Kuper and Kröpelin, 2006). For example, the drought-induced reduction in forest cover and the emergence of savanna corridors during the middle-Holocene enabled the Bantu to colonise what was once dense forest of the Congo and other regions of Africa (Grollemund et al., 2015; Oslisly et al., 2013). In central Asia, the horse-riding Scythian people capitalised on the transformation of hostile desert into steppe, brought about by higher rainfall in the last millennium BC (Van Geel et al., 2004). Similarly, the onset of more humid conditions in the central Eurasian steppes in the AD 13th century appears to have triggered the expansion of the largest contiguous land empire in world history, the Mongol empire (Pederson et al., 2014).

Similar to the Arawak expansion (Heckenberger, 2002), the Tupi-Guarani is one of the largest expansion of an ancient people in lowland South America spreading across $4000 \mathrm{~km}$ and stretching from southwestern (SW) Amazonia to the subtropical Atlantic coast of southeast (SE) South America (Figure 1). The cause of this mass human expansion remains a debated topic in New World archaeology, bioarchaeology, genetics and linguistics (Brochado, 1989; Eriksen and Galucio, 2014; Heckenberger et al., 1998; Marrero et al., 2007; Miller, 2009; Neves, 2011; Neves et al., 2011; Noelli, 1998; Rodrigues and Cabral, 2012; Walker et al., 2012). Similar to other cases of language spread with farmers' demic diffusion (Diamond and Bellwood, 2003), the explanation for the Tupi-Guarani dispersal out of Amazonia has been demographic growth propelled by agriculture, coupled with a

\footnotetext{
'Department of Archaeology, College of Humanities, University of Exeter, UK

${ }^{2}$ School of Archaeology, Geography and Environmental Science,

University of Reading, UK

${ }^{3}$ Department of Geography, Northumbria University Newcastle, UK

${ }^{4}$ School of Geographical Sciences, University of Bristol, UK
}

\section{Corresponding author:}

José Iriarte, Department of Archaeology, College of Humanities, University of Exeter, Laver Building, North Park Rd., Exeter EX4 4QE, UK. Email: J.Iriarte@exeter.ac.uk 
strong territoriality, long-range political networks, and an expansionist warlike ideology (Brochado, 1989; Noelli, 1998). However, an explanation relying solely on socio-political and economic causes fails to account for either the timing or route of the Tupi-Guarani expansion (Scheel-Ybert et al., 2014). Early attempts to link climate change with the expansion of the TupiGuarani are based on limited and now outdated palaeoecological reconstructions. Drawing on refuge theory (Haffer, 1974; Prance, 1982) and the available palaeoecological records (e.g. Ab'Saber, 1977; Absy, 1979), Meggers (1982) and Migliazza (1982) suggest that the Tupi-Guarani expansion out of SW Amazonia was a response to the onset of drier climatic episodes that reduced the forest around $2 \mathrm{k}$ cal. yr BP forcing Tupi-Guarani groups to migrate to other regions. This scheme was followed by several Brazilian archaeologists (e.g. Schmitz, 1991) in their interpretation of Tupi-Guarani migrations. In a recent review of palaeoecological data, Neves (2013) called the attention to the correlation between a trend of increasing humidity around $3.5 \mathrm{k}$ cal. yr BP and the spread of economic strategies traditionally denominated the 'tropical forest pattern' across the whole Amazon. Neves (2013) suggests that the climate changes that took place between the mid- and late-Holocene likely 'triggered a stronger reliance on these diverse agroforestry systems and the establishment of large sedentary settlements across the area'. However, this study restricted to Amazonia did not link the increased climatic humid conditions with the migration of populations either within or outside of Amazonia. More recently, Bonomo et al. (2015) carried out the latest synthesis of the nature and pace of the Guarani expansion SE South America. Based on a couple of geomorphological studies (Iriondo and Garcia, 1993; Stevaux, 2000), these authors played down the role of climate in the expansion of the Guarani in SE South America by stating that 'The climatic oscillations during this period do not appear to have a strong influence on the identified pulses of Guarani expansion, which transcends dry, warm, and humid moments'. Furthermore, they do not connect the expansion of the Guarani in the Rio de la Plata basin to their SW Amazonia homeland.

Despite the relative wealth of palaeoclimate, palaeoecological and archaeological data from this region of lowland South America that have accumulated during the last three decades, until now, the relationship between the expansion of this linguistic family of forest farmers and climate change out of Amazonia has not been adequately explored in the light of recent data. As a result, although the fine-scale pattern of the Tupi-Guarani settlement in SE South America is coming into sharper focus (Bonomo et al., 2015), the potential role of climate change as the root cause of the continentalscale Tupi-Guarani expansion has never been properly evaluated.

\section{Materials and methods}

To assess the role of climate in the expansion of the Tupi-Guarani out of Amazonia, we have marshalled archaeological, palaeoclimate and palaeoecological datasets to test our hypothesis that increasing late-Holocene precipitation drove forest expansion, which in turn facilitated the expansion of the Tupi-Guarani culture from SW Amazonia across SE South America. We do this by synthesising data from 197 dated archaeological sites from the Guarani, who represent the southernmost branch of the TupiGuarani family (Figure 2, Section S1, Tables S1 and S2, available online), 3 representative palaeo-precipitation records (Figure 2, Section S2, available online) and 73 palaeoecological records (Figure 2, Section S3, Tables S3-S6, available online). Because all these records lie within the path of the South American LowLevel Jet (SALLJ) (Figure S1, available online), the key mechanism for moisture transport across lowland South America, we are able to explore the relationship between climate change, forest expansion and Guarani expansion.

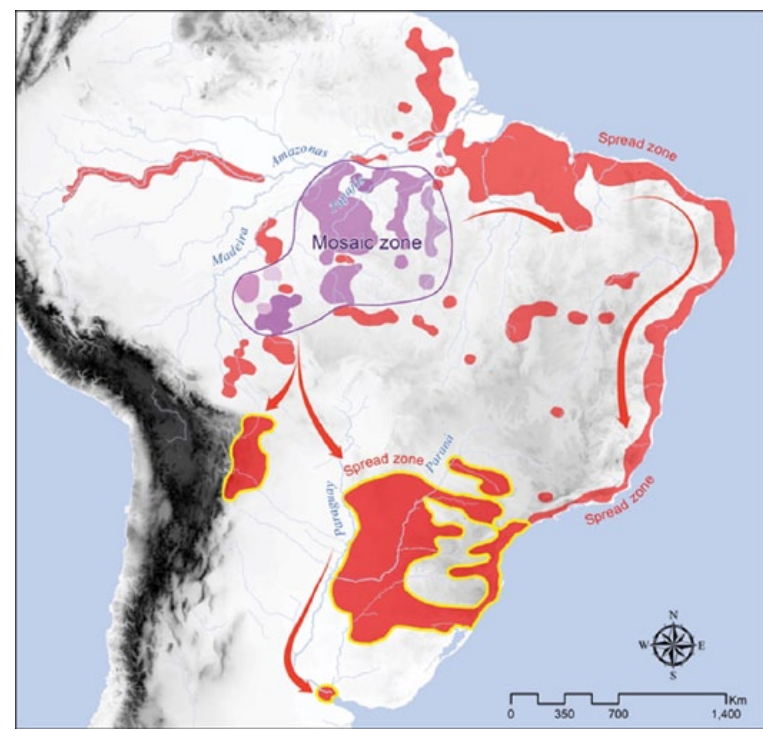

Figure I. Historical distribution of the languages of the TupiGuarani family (red) and other families of the Tupían stock (shades of purple). Languages of the Group I (Guarani) are outlined in yellow. The map shows the Tupían mosaic zone characterised by high linguistic diversity resulting from a long period of uninterrupted divergence in the purported homeland of the stock originating in SW Amazonia and the Guarani spread zone, illustrating how this single language family rapidly dispersed over SE South America replacing previous languages.

\section{Results}

\section{Evidence for the Guarani expansion}

The Tupían linguistic stock is one of the largest of lowland South America. It consists of around 60 languages grouped into 10 linguistic families, of which the Tupi-Guarani family is the most widely dispersed - being the only one extending beyond Amazonia (Rodrigues and Cabral, 2012) (Figure 1 and Figure S2, available online). At the time of the Portuguese arrival to the Brazilian coast (AD 1500), Tupi-Guarani speakers numbered in the millions (Viveiros de Castro, 1992). In the La Plata Basin and the whole of the Brazilian Atlantic Coast, they occupied a riverine and coastal network spanning over $4000 \mathrm{~km}$, and Tupi-Guaranibased lingua francas were still widely used in Brazil as recently as the 19th century (Noelli, 1998; Walker et al., 2012).

In SE South America, the historically recorded Tupi-Guarani groups were organised in regional chiefdoms constituted by confederacies of villages under the influence of a prominent political or spiritual leader (Milheira and DeBlasis, 2014; Noelli, 1998). War expeditions travelled hundreds of kilometres through major waterways to attack enemies, conquer territories, capture women, and, in some cases, enslave the defeated (Brochado, 1989; Santos-Granero, 2009). The strong bellicose ethos and predatory cosmology of the Tupi-Guarani included anthropophagic ritual feasting, which had a large social significance as a means of status acquisition until colonial times (Brochado, 1989; Fausto, 2012; Milheira and DeBlasis, 2014; Viveiros de Castro, 1992). Unlike other Amazonian language expansions that appear to have spread through trade and a pacific ethos (e.g. Arawak), historical TupiGuarani groups have long been perceived as inclined towards expansion and conquest (Hornborg et al., 2005).

The Tupi-Guarani lived in large palisaded villages (Figure 3), with almost all archaeological sites situated in forests close to navigable rivers (Scheel-Ybert et al., 2014). Management of forests was a key component of the Tupi-Guarani economy, including the introduction of plants to prepare the environment before their definitive annexation of a newly settled area (Noelli, 1998). 
They practised agroforestry polyculture, complemented with fishing, hunting and gathering (Noelli, 1998; Scheel-Ybert et al., 2014) and their expansion marks the widespread adoption of agriculture in SE South America, bringing with them 24 varieties of manioc (Manihot esculenta), 13 varieties of maize (Zea mays), 15 varieties of beans (Phaseolus vulgaris) and 21 varieties of sweet potato (Ipomoea batatas), among many other cultivated plants (Brochado, 2001; Noelli, 1993). The distribution of sites indicates that the Tupi-Guarani did not select a particular type of forest, but expanded on a variety of forest types including close canopy tropical forest, dry forest and gallery forest. It appears that the determining factor for the Tupi-Guarani colonisation is the presence of a tree cover for practising agroforestry. Linguistic evidence indicating the presence of reflexes of the same name for

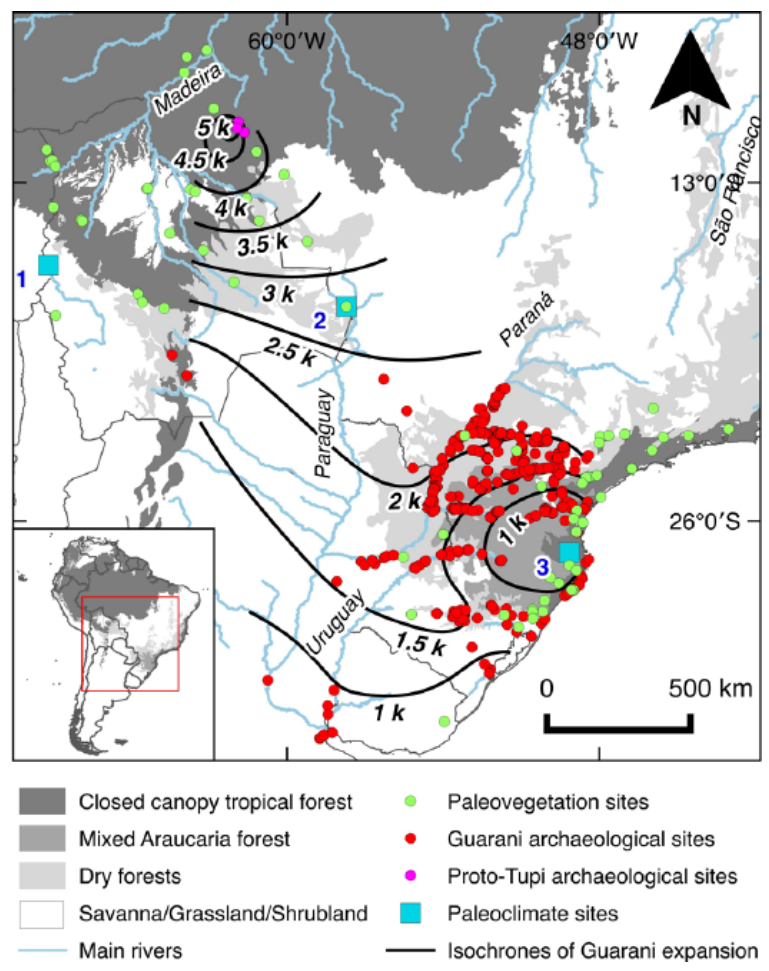

Figure 2. Map of study area showing modern vegetation (Olson et al., 200I), locations of I I8I Guarani and Proto-Tupi archaeological sites (see Tables SI and S2, available online), palaeoecological sites (see Table S6, available online) and palaeoclimate sites, including (I) Lake Titicaca, (2) Laguna La Gaiba and (3) Botuverá Cave (Section S2, available online). Isochrones show the time-transgressive movement of the Guarani culture ( $k=k$ cal. yr BP). 'cultivated patch of land' in 9 of the 10 linguistic families of the Tupi stock suggests that the speakers of the Proto-Tupi language practised agriculture reinforcing the idea that this was an agricultural expansion (Rodrigues, 2010). This argument is further strengthened by the presence of similar names for agricultural tools such as digging stick and axe, as well as major crops including manioc, sweet potato and yams in nearly all linguistic families of the stock (Rodrigues, 2010).

Despite the paucity of archaeological data in SW Amazonia (Macario et al., 2009), this region is considered to be the centre of origin of the Tupían stock, based upon linguistic (Miller, 2009; Rodrigues and Cabral, 2012; Walker et al., 2012), cranial morphological (Hubbe et al., 2014; Neves et al., 2011) and genetic data (Marrero et al., 2007; Santos et al., 2015). Five of the 10 families of the Tupían stock are restricted to the modern state of Rondônia, Brazil (Eriksen and Galucio, 2014). It has long been recognised that such depth of ethnolinguistic diversity points to SW Amazonia as the homeland of the Tupían stock (Eriksen and Galucio, 2014; Rodrigues and Cabral, 2012; Walker et al., 2012). Linguists estimate that the Tupían stock initially split between $5 \mathrm{k}$ and $3 \mathrm{k}$ cal. yr BP, after which the Tupi-Guarani family split around $3 \mathrm{k}-2 \mathrm{k}$ cal. yr BP (Migliazza, 1982; Rodrigues and Cabral, 2012; Walker et al., 2012). Similarly, genetic data support SW Amazonia as the purported place of origin of the Tupían groups (Marrero et al., 2007; Santos et al., 2015). Analyses of variability in autosomal and uniparental (Y-chromosome and mtDNA) genetic markers show agreement with the linguistic models, evidencing an early expansion from the Madeira-Guaporé basin and a later continent-wide population spread associated with the Tupi-Guarani (Santos et al., 2015) ca. 2.8k cal. yr BP (Amorim et al., 2013). Cranial morphological data also demonstrate that individuals from Tupi-Guarani archaeological contexts in SE South America are grouped more closely with the Amazonian series than with the local populations (Neves et al., 2011).

Archaeologically, the expansion of Tupi-Guarani groups throughout eastern lowland South America coincides with the distribution of polychrome pottery, which is very distinctive from local traditions, but has prototypes in Amazonia (Bonomo et al., 2015; Brochado, 1989; Noelli, 1998). In spite of their expansion over thousands of kilometres, Tupi-Guarani sites show remarkably homogeneous material culture and settlement patterns characterised by the occurrence of anthropogenic dark earth located along major waterways associated with riverine forests (Bonomo et al., 2015; Scheel-Ybert et al., 2014). In historical times, Tupi-Guarani groups of SE South America were superb canoe navigators, which eased their dispersal along major waterways (Brochado, 1989).

Central Amazonia was initially thought to be the cradle of polychrome ceramics (Brochado, 1989), but recent archaeological data show that polychrome ceramics are a recent dispersal in that area,
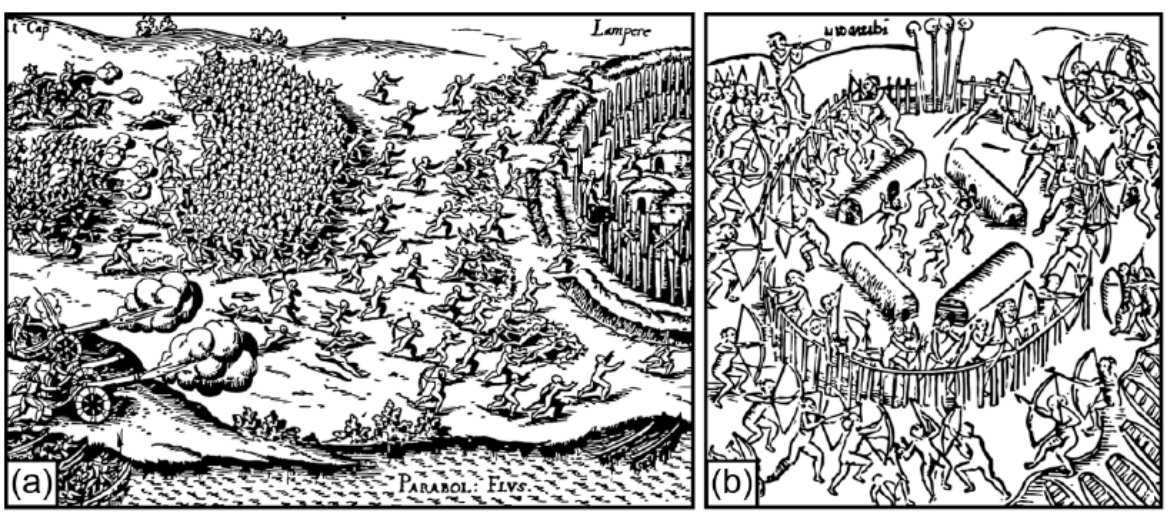

Figure 3. Historical depictions of Tupi-Guarani palisaded villages: (a) Spanish attack on a Guarani village, Paraguay river (Schmidl, I599 [1567]) and (b) war among the Tupinambá, Rio de Janeiro coast (Staden, I557). 

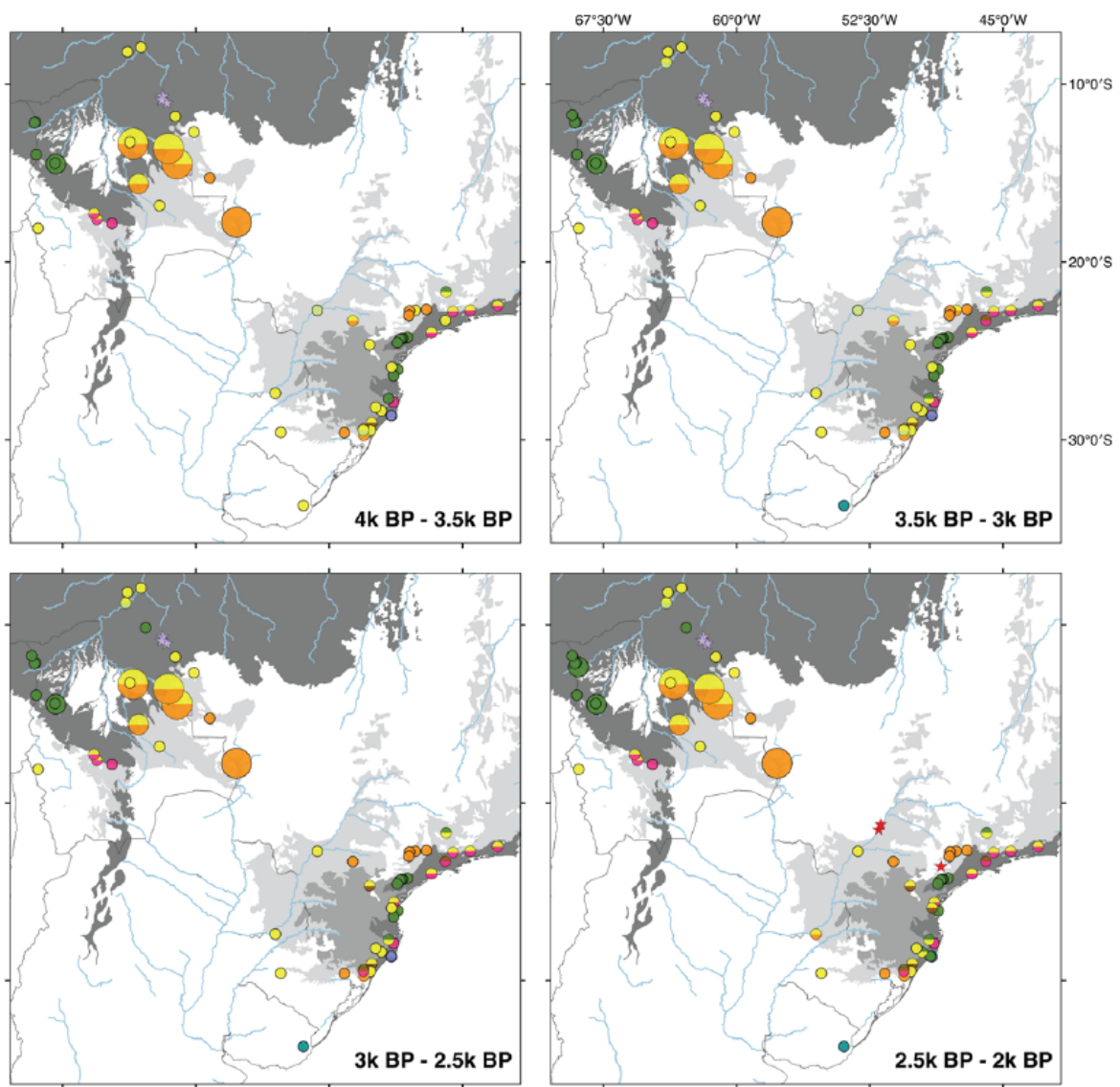

\begin{tabular}{|c|c|c|c|}
\hline Modern vegetation types & Palaeoecological classific & ations & $\stackrel{0}{5} 500 \mathrm{~km}$ \\
\hline orest & est & st & $\star$ Guarani archaeological sites \\
\hline Mixed Araucaria forest & $\square$ Mixed Araucaria forest & ric forest & $\begin{array}{l}\text { Guarani archaeological sites } \\
\text { (from previous time steps) }\end{array}$ \\
\hline Dry forests & $\square$ Dry forests & $\square$ Wetlands/Marsh & pi archaeological sites \\
\hline $\begin{array}{l}\text { Savanna/Grassland/Shrubla } \\
\text { - Main rivers }\end{array}$ & $\begin{array}{l}\square \text { Savanna/Grassland/Shrubland } \\
\square \text { Cloud/montane forest }\end{array}$ & $\begin{array}{l}\square \text { Coastal lagoon } \\
\square \text { Mangrove }\end{array}$ & $\begin{array}{l}\text { Proto-Tupi archaeological sites } \\
\text { (from previous time steps) }\end{array}$ \\
\hline
\end{tabular}

Figure 4. Archaeological and palaeoecological data at $0.5 \mathrm{k}$ cal. yr BP (500 year) time slices from $4 \mathrm{k}$ to $2 \mathrm{k}$ cal. yr BP (see Sections SI and S2 and Movie SI for visualisation in motion, available online). Maps of modern vegetation (Olson et al., 200I).

and too late to be related to the Tupi-Guarani expansion (Heckenberger et al., 1998). The Upper Madeira, SW Amazonia, is presently the area with the earliest polychrome ceramics and anthropogenic dark earths (Neves, 2011), with dates of 5k-3k cal. yr BP for ceramic sites in this region (Table S1, available online), coinciding with the glottochronological estimates for the initial split of the Tupían stock. Beyond Amazonia, ceramics recognisable as Tupi-Guarani appear from $3 \mathrm{k}$ to $2 \mathrm{k}$ cal. yr BP (Bonomo et al., 2015; Brochado, 1989; Macario et al., 2009; Noelli, 1998) (Table S2, available online), in agreement with linguistic estimates.

This expansion took place at a time of widespread cultural change towards increasingly complex societies and the spreading of linguistic families across lowland tropical South America, including the Arawak (Clement et al., 2015; Heckenberger, 2002) and the Jê (Noelli, 2005). This is also a time when lowland societies began to transform the landscape at a scale not seen before. Extensive agricultural landscapes, such as raised-field systems in seasonally flooded savannas, began to be built from French Guiana to the Llanos de Moxos in Bolivia, while Amazonian Dark Earths, possibly associated with sedentism and intensive agriculture, appeared mainly along the bluffs of major rivers in Amazonia (Arroyo-Kalin, 2010; Heckenberger and Neves, 2009; Neves, 2011).

It is clear that, despite the lack of crucial archaeological data in the Upper Guaporé River and the Cerrado connecting SW Amazonia to SE South America, current linguistic, genetic, cranial morphological and available archaeological data suggest that the Tupi-Guarani family split and began to spread southwards from Amazonia to SE South America (Figures 2 and 4 ) by about $3 k-2 k$ cal. yr BP (Bonomo et al., 2015; Noelli, 1998; Rodrigues and Cabral, 2012). The archaeological data (Figures 2 and $6 \mathrm{c}$ ) show that the Tupi-Guarani expanded beyond the 'mosaic zone' (Bellwood and Renfrew, 2002) of SW Amazonia to reach the 'spread zone' (Figure 1) of this linguistic family in SE South America by about $2.5 \mathrm{k}$ cal. yr BP, giving rise to the Guarani Tradition south of the $17^{\circ} \mathrm{S}$ parallel (Bonomo et al., 2015; Noelli, 1998).

\section{Routes of expansion}

Unlike their ancestors, who occupied interfluvial areas, the expansion of the Guarani out of Amazonia exclusively followed major rivers (Almeida and Neves, 2015). Archaeology is beginning to show that Tupi-Guarani groups in the Amazon basin were living in smaller, possibly less permanent interfluvial villages, facing the competition of Arawak settlers in the varzeas. It is only when the Tupi-Guarani expanded outside Amazonia towards the Paraná basin and the Atlantic coast that the pattern of large fortified villages along major waterways, expansive warfare, and conquest appears to have taken hold (Almeida, 2015; Almeida and Neves, 2015).

Regardless of debates about the specific routes taken by the various Tupi-Guarani groups in their expansion throughout South America, there is general agreement that the upper Paraguay and 
Paraná rivers served as the main waterway routes for the southward spread of the Guarani from their homeland in SW Amazonia (Brochado, 1989; Noelli, 1998). The most widely accepted riverine route for the southward expansion of the Tupi-Guarani passes through the Upper Madeira-Guaporé river, bordering the Llanos de Moxos, to reach the Upper Paraguay river in the vicinity of the Pantanal wetland, from where the Guarani could spread, via major fluvial courses, to the whole La Plata Basin and the adjacent coast (Brochado, 1989; Noelli, 1998). This proposed route is supported by the proximity of the Guarani to languages of Bolivia (Guarayu and Siriono) (Brochado, 1989; Noelli, 1998) and because Guarani archaeological ceramics include forms and decorations (conical corrugated jars) acquired from eastern Bolivian traditions (Brochado, 1989). Unfortunately, although several Guarani sites have been documented in the Upper and Middle Paraguay river, they have not yet been dated (Bonomo et al., 2015) and at present the Upper Paraná holds the earliest dates. Future research in the region between the western border of the Pantanal and the Upper Guaporé will be crucial to fill the gap between the Tupían homeland in SW Amazonia and the beginning of the Guarani tradition in the Upper Paraguay river (Noelli, 1998).

Riverine gallery forests of the Llanos de Moxos savanna wetland and the Gran Chaco scrub may have also served as key routes of expansion for the Guarani out of Amazonia towards the Paraguay-Paraná system. Like the Amazon River system, the La Plata Basin comprises a network of huge rivers that constituted a major avenue for communication among different pre-Columbian groups that had watercraft. There are no important geographical barriers that separate these two large river systems. Therefore, the annual inundation of the Llanos de Moxos and Pantanal basins merges the watersheds of the Rio Madeira and the Rio Paraguay into a vast 'freshwater sea', opening up a network of waterways extending far south to the Rio de la Plata estuary.

Another potential route of expansion may have been via the Cerrado. One might expect that the extensive Cerrado (savanna) biome of south-central Brazil (covering ca. 2,000,000 km²), which separates the Amazonian and Atlantic forest biomes (Figures 2 and 4), would present a major environmental barrier to the Guarani culture reaching the Atlantic Forest biome of SE Brazil. However, when considered at finer spatial scales, the Cerrado biome is not a uniform expanse of savanna, but instead a highly heterogeneous forest-savanna mosaic. The savanna is confined to highly infertile soils and is interspersed with islands of semi-deciduous tropical forest on mesotrophic soils and extensive ribbons of riverine gallery forest which connect with both Amazonian and Atlantic Forest biomes. More recently, Almeida and Neves (2015) have hypothesised an eastern Amazonian origin for the Tupi-Guarani; however, the Tupi-Guarani dates in eastern Amazonian are contemporaneous with the Guarani dates on the Upper Paraná, therefore, refuting this hypothesis until more research is carried out. Last but not least, we should not discard the possibility that a few founder populations 'leapfrog' (sensu Fiedel and Anthony, 2003) from SW Amazonia to the Atlantic Forest, where they found the perfect niche and started their expansion from there. This hypothesis is supported by the relatively early chronology of the Morro Grande site in Rio de Janeiro state, which belongs to the Tupinamba Tradition and dates back to around 2.9k cal. yr BP (Macario et al., 2009; Scheel-Ybert et al., 2008). The probability that this initial long-distance leap may also have been followed by later subsequent expansion episodes from this region as forest expanded across SE South America should also be taken as a testable hypothesis for future studies. However, at the moment, this argument leaves unexplained how the earliest Guarani sites appear in the Upper Paraná River and not in the Atlantic forest as this scenario would predict.

Regardless of the particular mechanism or route they took, once they arrived in the upper La Plata Basin, several waves of expansion of the Guarani across SE South America can be clearly identified with current data: (1) ca. $2.5 \mathrm{k}-2 \mathrm{k}$ cal. yr BP, onset of colonisation of the Upper Paraná river; (2) ca. $2 \mathrm{k}-1.5 \mathrm{k}$ cal. yr BP, settlement along the Uruguay river; (3) ca. $1.5 \mathrm{k}-1 \mathrm{k}$ cal. yr BP, onset of colonisation of the Southern Brazilian coast; and (4) after ca. 1k cal. yr BP, establishment of the southernmost Guarani settlements in the Paraná Delta (Bonomo et al., 2015) (Figures 2 and 4, Movie $\mathrm{S} 1$, available online). This expansion conforms to a dendritic pattern, whereby the first settlements in a newly colonised area always occurred along major forested waterways. It was only after the occupation of these preferred environments had been consolidated that colonisation of small tributaries ensued (Bonomo et al., 2015). The southward movement from Amazonia across SE South America represents a process of expansion, rather than migration, because daughter villages branched out of over-populated parent villages while maintaining interaction and social ties with them, so that old territories were never abandoned. This process resulted in an expanding radius of village networks through gradual population waves following the major forested river courses (Noelli, 1998). It has been well-documented in the Pardo river valley, Rio Grande do Sul, where it has been clearly shown that the earliest and larger sites occupy the fertile floodplain, whereas the latest sites are smaller and located in higher elevations (Rogge, 2005).

\section{Evidence for climate-driven forest expansion in the Holocene}

Most of the rainfall in the southern hemisphere tropics of South America is seasonal and monsoonal in character. During the austral summer, the SALLJ (Zhou and Lau, 1998) transports moisture generated by deep convection in the core of the Amazon basin south-westwards towards the foothills of the Andes. From here, it is deflected along the eastern flank of the Bolivian Andes along a diagonal path towards southern Brazil, where it exits the continent at the South Atlantic convergence zone (Figure S1, available online).

Palaeoclimate records in the regions influenced by the SALLJ Lake Titicaca (the Altiplano) (Baker et al., 2001), Laguna La Gaiba (the central lowlands) (Whitney and Mayle, 2012) and Botuverá Cave (southern Brazil) (Cruz et al., 2005) - all demonstrate a consistent long-term trend of increasing precipitation starting during the mid-Holocene ( $\sim 6 \mathrm{k}$ cal. yr BP), showing a rapid rise up to $4 \mathrm{k}$ cal. yr $\mathrm{BP}$, and then continued to increase slightly towards the present (Figure $6 \mathrm{a}$, Section S2, available online). This trend has been attributed to a progressive strengthening of the monsoon over this period as orbital forcing (precession cycle) increases austral summer insolation (Figure S1, available online) (Berger and Loutre, 1991). Modelled rainfall from Hadley Centre climate model (HadCM3) simulations covering the last $6 \mathrm{k}$ cal. yr BP (Section S2 and Figure $\mathrm{S} 4$, available online) is in line with these palaeoclimate reconstructions and demonstrates that the palaeoclimate proxy data reflect climate change across our study area as a whole. Our palaeovegetation data syntheses (Figure 6b) show that, despite some variability in the spatio-temporal pattern of forest dynamics among sites - due to a range of factors, such as the diversity of vegetation types (Figure 2), distance from an ecotone (Mayle et al., 2000), pollen catchment size (Carson et al., 2014), geomorphology, edaphic conditions, degree of human impact (Carson et al., 2014) - the proportion of sites with a forest-dominated catchment increases consistently through the midlate-Holocene, between around 5k and $1 \mathrm{k}$ cal. yr BP (Figures 4-6b, Movie S1, available online). This is exemplified by (1) the expansion of the southern Amazon rainforest margin (Carson et al., 2014; Flantua et al., 2015; Mayle et al., 2000); (2) expansion of seasonally dry tropical forest margins in the Chiquitanía region of lowland Bolivia and at the southern margin of the Cerrado (savanna) biome (Ledru, 1993; Oliveira-Filho and Ratter, 1995), the expansion of gallery forests in the central Brazilian savannas (Silva et al., 2008); (3) the development of dry forest in the Misiones region of southern 

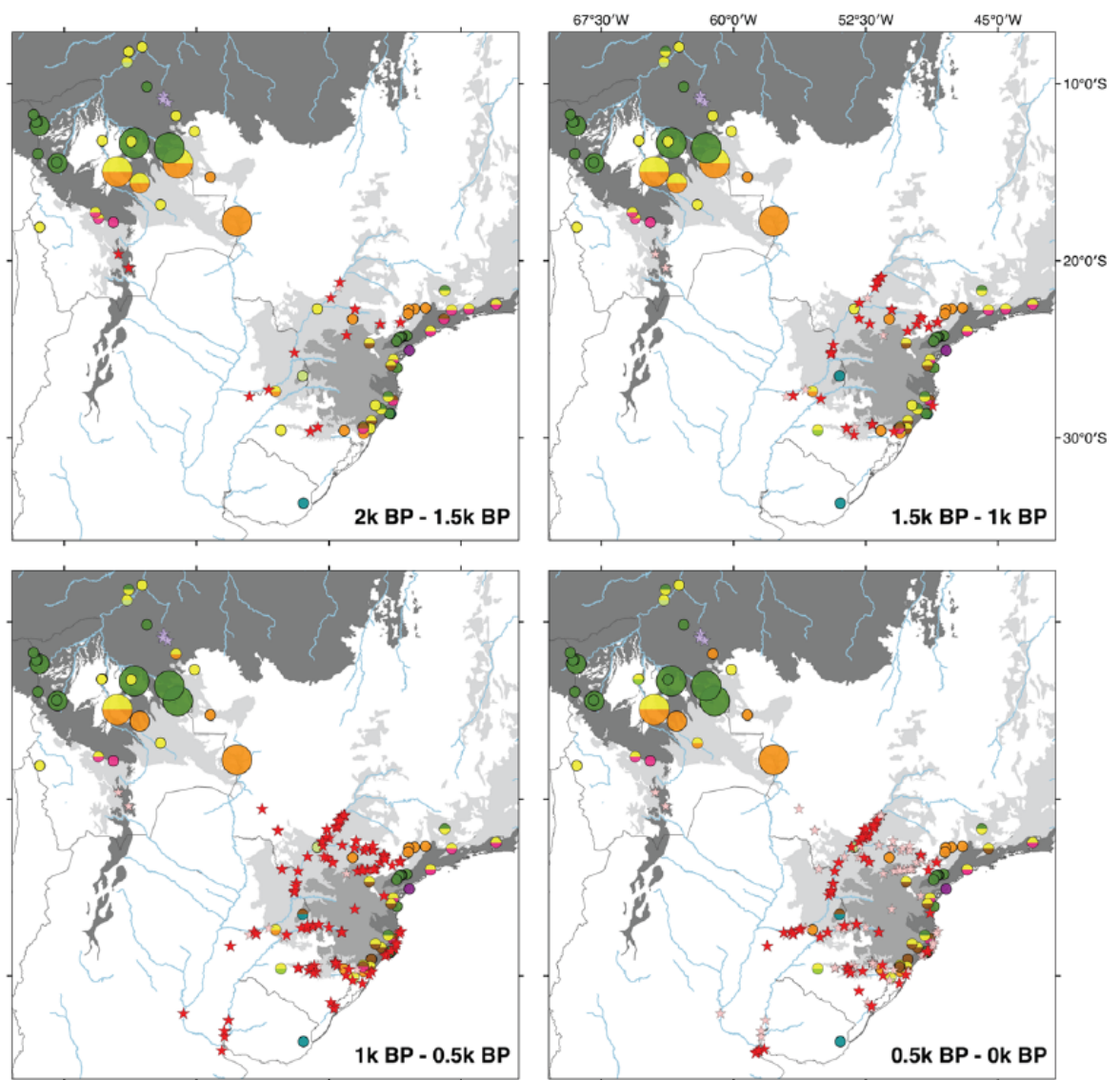

\begin{tabular}{|c|c|c|c|}
\hline Modern vegetation types & Palaeoecological classifice & ations & $500 \mathrm{~km}$ \\
\hline orest & est & st & $\star$ Guarani archaeological sites \\
\hline Mixed Araucaria forest & $\square$ Mixed Araucaria forest & $\square$ Generic forest & $\begin{array}{l}\text { Guarani archaeolog } \\
\text { (from previous time }\end{array}$ \\
\hline Dry forests & $\square$ Dry forests & $\square$ Wetlands/Marsh & $\star$ Proto-Tupi archaeological sites \\
\hline $\begin{array}{l}\text { Savanna/Grassland/Shrubla } \\
\text { Main rivers }\end{array}$ & $\begin{array}{l}\square \text { Savanna/Grassland/Shrubland } \\
\square \text { Cloud/montane forest }\end{array}$ & $\begin{array}{l}\square \text { Coastal lagoon } \\
\square \text { Mangrove }\end{array}$ & $\begin{array}{l}\text { \# Proto-Tupi archaeological sites } \\
\text { (from previous time steps) }\end{array}$ \\
\hline
\end{tabular}

Figure 5. Archaeological and palaeoecological data at $0.5 \mathrm{k}$ cal. yr BP (500 year) time slices from $2 \mathrm{k}$ cal. yr BP to present (see Sections SI and S2 and Movie SI for visualisation in motion, available online). Maps of modern vegetation (Olson et al., 200I).

Brazil (Zech et al., 2009); and (4) the development and expansion of Araucaria forests in the southern Brazilian highlands (Behling and Pillar, 2007). This temporal pattern of forest expansion follows the trend of increasing rainfall through the mid-late-Holocene, pointing to a causal relationship (Figures 4 and 5). As previously suggested by other authors such as Behling (2002) and Marchant and Hooghiemstra (2004), we infer that progressive strengthening of the austral summer monsoon (and consequent reduction in length/severity of the dry season) over this period enabled forest expansion at the expense of more drought-tolerant savanna/grassland ecosystems. Furthermore, the recent study by Spracklen et al. (2012) based on remote sensing and pan tropical vegetation patterns has shown that the air that passes over extensive vegetation produces at least twice as much rain as air that passed over little vegetation. Therefore, the expansion of forest over more open areas must have also had a positive feedback on the increase of precipitation.

\section{Discussion}

The period of climate-driven forest expansion in SW Amazonia and SE South America (ca. 5k-1k cal. yr BP) encompasses the period of Tupi-Guarani expansion $(\sim 2.5 \mathrm{k}-1 \mathrm{k}$ cal. yr BP) across this region (Figures 4 and 5). High quality palaeoclimate data from Lake Titicaca can be considered as a 'rain gauge' for SW Amazonia because most of the precipitation reaching this high Andean site is derived from advected Amazonian moisture delivered via the SALLJ. Progressive strengthening of the monsoon and increased moisture delivery via the SALLJ caused lake-level to rise by $90 \mathrm{~m}$ from its $6 \mathrm{k}$ cal. yr BP lowstand to reach near-modern levels by $3 \mathrm{k}$ cal. yr BP (Figure 6a, Figure S4, available online). By $2.5 \mathrm{k}$ cal. yr BP, climate-driven rainforest expansion in SW Amazonia (Mayle et al., 2000) may have been sufficient to facilitate the initial wave of expansion of the Tupi-Guarani out of Amazonia.

It is likely that rising precipitation through the mid-lateHolocene (Figure 6a, Figure S4, available online) would have increased river levels (making them even more navigable by the Guarani culture) which in turn would have led to expansion of gallery forests within which new Tupi-Guarani villages could be established. Subsequent waves of Guarani expansion from $2 \mathrm{k}$ cal. yr BP until European Conquest (0.5k cal. yr BP) occur in phase with continued climate-driven forest expansion (Figure 5, Figure S5 and Movie S1, available online).

A comparison of the time of first increase in vegetation score and the age of the archaeological sites in SE South America clearly shows that forest expanded immediately before or concomitant with the arrival of the Guarani, within the limits of the chronological resolution of our data. The general trend shows that, as the forest expands southwards, the Guarani colonisation ensues. For example, in the middle Paranapanema $\left(22^{\circ} \mathrm{S}\right)$, forest expansion begins around $4 \mathrm{k}-3.5 \mathrm{k}$ cal. $\mathrm{yr} \mathrm{BP}$ and vegetation fully converts to forest by $3 \mathrm{k}-2.5 \mathrm{k}$ cal. yr BP (Figure 6). The Guarani arrival in the Upper Paraná and later expansion to the Paranapanema soon follows at $2.5 \mathrm{k}-2 \mathrm{k}$ cal. yr BP. Increases in vegetation score occur later as one progresses further south, dating to $2.5 \mathrm{k}-2 \mathrm{k}$ cal. yr BP 
(a)

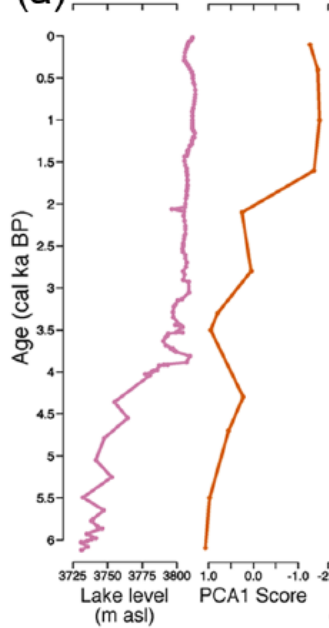

Botuvera

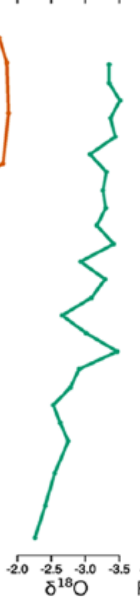

HadCM3 Jan. insolation

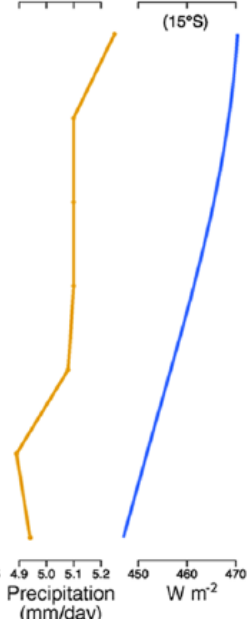

(b)

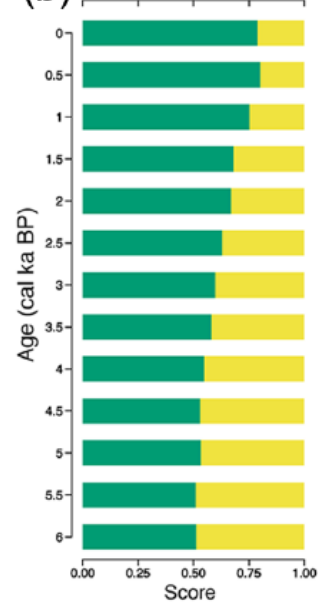

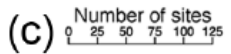

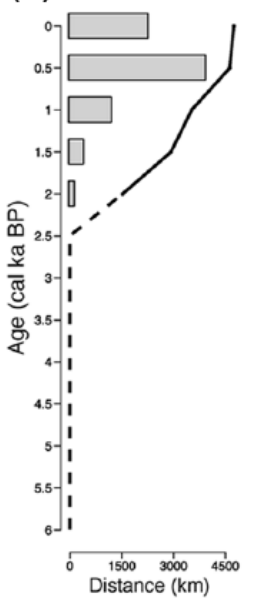

Figure 6. (a) Selected palaeoclimate records representing proxies for precipitation changes over the last $6 \mathrm{k}$ cal. yr BP, including lake-level changes as measured by $\delta^{13} \mathrm{C}$ at Lake Titicaca (Rowe et al., 2002); Pediastrum inferred lake-level change at Laguna La Gaiba (Whitney and Mayle, 2012); $\delta^{18} \mathrm{O}$ of stalagmite BTV3A from Botuverá Cave (Wang et al., 2007) (Section S2, available online). Palaeoclimate data are shown in relation to HadCM3 simulated precipitation and calculated January insolation at $15^{\circ} \mathrm{S}$ (Berger and Loutre, 199l). (b) Vegetation scores of forested (green) and non-forested (yellow) palaeoecological sites. The vegetation scores are a representation of the proportion of palaeoecological sites that reflect open versus forested vegetation at a given time slice, with weighting applied according to the relative spatial coverage represented by each vegetation reconstruction (Section S3, available online). (c) Number of Guarani archaeological sites per 500-year time slices (Tables S1 and S2, available online). The curve shows maximum cumulative distance travelled at each time slice to colonise new areas out of Amazonia (Section SI and Figure S3, available online). The dashed line shows the probable distance travelled from the Tupían homeland to SE South America.

in the middle Paraná $\left(27^{\circ} \mathrm{S}\right)$ (Figures 4 and 5). This trend is immediately accompanied by the Guarani expansion down the Paraná around $2 \mathrm{k}-1.5 \mathrm{k}$ cal. yr BP. Finally, in the Ibicuí river $\left(30^{\circ} \mathrm{S}\right)$, the first increase in vegetation score takes place at $1.5 \mathrm{k}-1 \mathrm{k}$ cal. yr BP, preceding the southernmost movement of the Guarani towards the Paraná Delta $\left(35^{\circ} \mathrm{S}\right)$ at $1 \mathrm{k}-0.5 \mathrm{k}$ cal. yr BP (Figure 5).

\section{Conclusion}

Although east-west migrations are in general more common than north-south movements because the former are less likely to encounter variation in climate and habitat (Diamond and Bellwood, 2003), the Guarani expansion from SW Amazonia to the Paraná River Delta constitutes a remarkable latitudinal shift. Arguably, it is the climatic link between these two end regions, created by the SALLJ (Figure S1, available online), and expansion of the preferred Guarani environment (riverine forest) in a north-south direction, that allowed such a massive latitudinal expansion of the Guarani. The complex political organisation, long-distance village network and bellicose ethos of the Guarani (Noelli, 1998; Viveiros de Castro, 1992) were socio-political factors that certainly played a significant, proximal role in the Guarani expansion, but our data analysis suggests that climate change may have been the root cause that triggered the Guarani expansion across the broad temporal (millennial) and spatial (sub-continental) scales of our study. Our findings show that, by increasing the area of forested landscape that the Guarani could exploit, the climatedriven forest expansion created an ecological opportunity that facilitated the expansion of the Guarani forest-farming culture over their preferred familiar landscape. Our results suggest that the most likely explanation for the timing of Guarani expansion, ca. $3 \mathrm{k}-2 \mathrm{k}$ cal. yr BP, is the climate-driven forest expansion across southern hemisphere South America at this time.

Other tropical agriculturalists which underwent major expansion, such as the Bantu farmers in Africa, appear to have avoided rainforest, instead preferring savanna corridors and forest openings that were likely caused by a mid-late-Holocene change to progressively drier climatic conditions (Grollemund et al., 2015; Oslisly et al., 2013). In contrast, the Guarani appear to have taken full advantage of climate-driven forest expansion to spread along the major rivers connecting southeastern South America with their ancestral homeland in SW Amazonia. As has been suggested for other climate-driven events of increased warfare and spread of fortified settlements (Field and Lape, 2010), the ecological opportunity offered by forest expansion might have also nurtured the Tupi-Guarani expansive ethos. Furthermore, the late-Holocene expansion of seasonally dry forests south of the Amazon likely eased Guarani spread because (1) soils beneath seasonally dry forest are generally less weathered, and thus more fertile, than those of humid evergreen forests, and (2) seasonally dry forests are easier to clear for agroforestry, the prolonged dry season enabling early farmers to efficiently clear vegetation and prepare plots for planting with the simple use of fire.

In conclusion, our results contrast with (1) traditional hypothesis based on now outdated palaeoecological interpretations, which suggest that the reduction of forest during the purported dry period that took place around $2 \mathrm{k}$ cal. yr BP would have pushed the Tupi-Guarani farmers dependent on forest resources to migrate (Meggers, 1982; Migliazza, 1982) and (2) recent reviews which downplay the role of climate in the expansion of the Guarani (Bonomo et al., 2015). On the contrary, they show that a more humid late-Holocene climate promoted the expansion of forest outside of Amazonia, which in turn, allowed the continental spread of the Amazon Tupi-Guarani forest farmers. Our interdisciplinary investigation shows that the interaction of socio-cultural and environmental factors has been important in shaping human dispersal across South America.

\section{Funding}

The ideas and themes developed in this paper stem from a European Research Council project 'Pre-Columbian Amazon-Scale Transformations' (ERC-CoG 616179) to JI. The University of Reading's 'Centre for Past Climate Change' funded a writing workshop for this paper. RS was funded by an NERC 'Scenario' DTP PhD award. JGS was funded by a CAPES PhD scholarship (Ministry of Education, Brazil). JFC and MLC received postdoctoral funding from the University of Reading and the Arts and Humanities Research Council, respectively. 


\section{References}

Ab’Saber AN (1977) Espaços ocupados pela expansão dos climas secos na América do Sul, por ocasião dos períodos glaciales quaternários. Paleoclimas 3: 1-19.

Absy ML (1979) A Palynological Study of Holocene Sediments in the Amazon Basin. Amsterdam: University of Amsterdam.

Almeida FO (2015) A arqueologia dos fermentados: A etílica história dos Tupi-Guarani. Estudos Avançados 29: 87-118.

Almeida FO and Neves E (2015) Evidências arqueológicas para a origem dos Tupi-Guarani no leste da Amazônia. Mana 21: 499-525.

Ammerman AJ and Cavalli-Sforza LL (2014) The Neolithic Transition and the Genetics of Populations in Europe. Princeton, NJ: Princeton University Press.

Amorim CEG, Bisso-Machado R, Ramallo V et al. (2013) A Bayesian approach to genome/linguistic relationships in native South Americans. PLoS ONE 8: e64099.

Anthony DW (2009) The Horse, the Wheel, and Language: How Bronze-Age Riders from the Eurasian Steppes Shaped the Modern World. Princeton, NJ: Princeton University Press.

Arroyo-Kalin M (2010) The Amazonian formative: Crop domestication and anthropogenic soils. Diversity 2: 473-504.

Baker PA, Seltzer GO, Fritz SC et al. (2001) The history of South American tropical precipitation for the past 25,000 years. Science 291: 640 .

Behling H (2002) Carbon storage increases by major forest ecosystems in tropical South America since the Last Glacial Maximum and the early Holocene. Global and Planetary Change 33: 107-116.

Behling H and Pillar VDP (2007) Late Quaternary vegetation, biodiversity and fire dynamics on the southern Brazilian highland and their implication for conservation and management of modern Araucaria forest and grassland ecosystems. Philosophical Transactions of the Royal Society of London, Series B: Biological Sciences 362: 243-251.

Bellwood P and Renfrew C (2002) Examining the Farming/Language Dispersal Hypothesis. Cambridge: McDonald Institute for Archaeological Research.

Berger A and Loutre M-F (1991) Insolation values for the climate of the last 10 million years. Quaternary Science Reviews 10: 297-317.

Bonomo M, Angrizani RC, Apolinaire E et al. (2015) A model for the Guaraní expansion in the La Plata Basin and littoral zone of southern Brazil. Quaternary International 356: 54-73.

Brochado JP (1989) A expansão dos Tupi e da cerâmica da tradição policrômica amazônica. Dédalo 27: 65-82.

Brochado JP (2001) Tupi. In: Peregrine PE and Ember M (eds) Encyclopedia of Prehistory Volume 7. South America. New York: Springer, pp. 343-354.

Büntgen U, Myglan VS, Ljungqvist FC et al. (2016) Cooling and societal change during the Late Antique 'Little Ice Age' from 536 to around 660 AD. Nature Geoscience 9: 231-236.

Carson JF, Whitney BS, Mayle FE et al. (2014) Environmental impact of geometric earthwork construction in pre-Columbian Amazonia. Proceedings of the National Academy of Sciences 111: 10497-10502.

Clement CR, Denevan WM, Heckenberger MJ et al. (2015) The domestication of Amazonia before European conquest. Proceedings of the Royal Society of London B: Biological Sciences 282: 20150813.

Cruz FW, Burns SJ, Karmann I et al. (2005) Insolation-driven changes in atmospheric circulation over the past 116,000 years in subtropical Brazil. Nature 434: 63-66.

Diamond J and Bellwood P (2003) Farmers and their languages: The first expansions. Science 300: 597-603.

Eriksen L and Galucio AV (2014) The Tupian expansion. In: O'Connor L and Muysken P (eds) The Native Languages of South America: Origins, Development, Typology. Cambridge: Cambridge University Press, pp. 177-199.
Fausto C (2012) Warfare and Shamanism in Amazonia. Cambridge: Cambridge University Press.

Fiedel SJ and Anthony DW (2003) Deerslayers, pathfinders, and icemen: Origins of the European Neolithic as seen from the frontier. In: Rockman M and Steele J (eds) The Colonization of Unfamiliar Landscapes: The Archaeology of Adaptation. London: Routledge, pp. 144-168.

Field JS and Lape PV (2010) Paleoclimates and the emergence of fortifications in the tropical Pacific islands. Journal of Anthropological Archaeology 29: 113-124.

Flantua S, Hooghiemstra H, Vuillle M et al. (2015) Climate variability and human impact on the environment in South America during the last 2000 years: Synthesis and perspectives. Climate of the past Discussions 11: 3475-3565.

Grollemund R, Branford S, Bostoen K et al. (2015) Bantu expansion shows that habitat alters the route and pace of human dispersals. Proceedings of the National Academy of Sciences 112: 13296-13301.

Haffer J (1974) Avian Speciation in Tropical South America. Cambridge, MA: Nuttall Ornithological Club Publications.

Heckenberger MJ (2002) Rethinking the Arawakan diaspora: Hierarchy, regionality, and the Amazonian formative. In: Hill JD and Santos-Granero F (eds) Comparative Arawakan Histories: Rethinking Language Family and Culture Area in Amazonia. Urbana, IL: University of Illinois Press, pp. 99-122.

Heckenberger MJ and Neves EG (2009) Amazonian archaeology. Annual Review of Anthropology 38: 251-266.

Heckenberger MJ, Neves EG and Petersen JB (1998) De onde surgem os modelos? As origens e expansões Tupi na Amazônia Central. Revista de Antropologia 41: 69-96.

Hornborg A, Gassn R, Heckenberger M et al. (2005) Ethnogenesis, regional integration, and ecology in prehistoric Amazonia: Toward a system perspective 1. Current Anthropology 46: 589-620.

Hubbe M, Okumura M, Bernardo DV et al. (2014) Cranial morphological diversity of early, middle, and late-Holocene Brazilian groups: Implications for human dispersion in Brazil. American Journal of Physical Anthropology 155: $546-558$.

Iriondo MH and Garcia NO (1993) Climatic variations in the Argentine plains during the last 18,000 years. Palaeogeography, Palaeoclimatology, Palaeoecology 101: 209-220.

Kirch PV (2000) On the Road of the Winds: An Archaeological History of the Pacific Islands before European Contact. Los Angeles, CA: University of California Press.

Kuper R and Kröpelin S (2006) Climate-controlled Holocene occupation in the Sahara: Motor of Africa's evolution. Science 313: 803-807.

Ledru M-P (1993) Late Quaternary environmental and climatic changes in central Brazil. Quaternary Research 39: 90-98.

Macario K, Buarque A, Scheel-Ybert R et al. (2009) The longterm Tupiguarani occupation in southeastern Brazil. Radiocarbon 51: 937-946.

Marchant R and Hooghiemstra H (2004) Rapid environmental change in African and South American tropics around 4000 years before present: A review. Earth-Science Reviews 66: 217-260.

Marrero AR, Silva-Junior WA, Bravi CM et al. (2007) Demographic and evolutionary trajectories of the Guarani and Kaingang natives of Brazil. American Journal of Physical Anthropology 132: 301-310.

Mayle FE, Burbridge R and Killeen TJ (2000) Millennial-scale dynamics of southern Amazonian rain forests. Science 290: 2291-2294.

Meggers BJ (1982) Archaeological and ethnographic evidence compatible with the model of forest fragmentation. In: Prance GT (ed.) Biological Diversification in the Tropics: Proceedings of the Fifth International Symposium of the Association 
for Tropical Biology. New York: Columbia University Press, pp. 483-496.

Migliazza E (1982) Linguistic prehistory and the refuge model in Amazonia. In: Prance GT (ed.) Biological Diversification in the Tropics: Proceedings of the Fifth International Symposium of the Association for Tropical Biology. New York: Columbia University Press, pp. 497-519.

Milheira RG and DeBlasis P (2014) Tupi-Guarani archaeology in Brazil. In: Smith C (ed.) Encyclopedia of Global Archaeology. New York: Springer, pp. 7384-7389.

Miller ET (2009) A Cultura Cerâmica do Tronco Tupí no alto Ji-Paraná, Rondônia, Brasil: Algumas Reflexões Teóricas, Hipotéticas e Conclusivas. Revista Brasileira de Linguística Antropológica 1: 35-136.

Neves EG (2011) Archaeological cultures and past identities in the pre-Colonial Central Amazon. In: Hornborg A and Hill JD (eds) Ethnicity in Ancient Amazonia: Reconstructing past Identities from Archaeology, Linguistics, and Ethnohistory. Boulder, CO: University of Colorado Press, pp. 31-56.

Neves EG (2013) Was agriculture a key productive activity in pre-colonial Amazonia? The stable productive basis for social equality in the Central Amazon. In: Brondizio ES and Moran EF (eds) Human-Environment Interactions. Dordrecht: Springer, pp. 371-388.

Neves WA, Bernardo DV, Okumura M et al. (2011) Origin and dispersion of the Tupiguarani: What does cranial morphology say? Boletim do Museu Paraense Emílio Goeldi. Ciências Humanas 6: 95-122.

Noelli F (1993) Sem Tekohá não há Tekó. (Em Busca de um Modelo Etnoarqueológico da Aldeia e da Subsistência Guarani e sua Aplicação a uma Área de Domínio no Delta do Rio Jacuí - RS). Porto Alegre: Department of History, PUCRS.

Noelli F (1998) The Tupi: Explaining origin and expansions in terms of archaeology and of historical linguistics. Antiquity 277: 648-663.

Noelli FS (2005) Rethinking stereotypes and the history of research on Jê populations in South Brazil: An interdisciplinary point of view. In: Funari P, Zarankin A and Stovel E (eds) Global Archaeological Theory: Contextual Voices and Contemporary Thoughts. New York: Springer, pp. 167-190.

Oliveira-Filho AT and Ratter J (1995) A study of the origin of central Brazilian forests by the analysis of plant species distribution patterns. Edinburgh Journal of Botany 52: 141-194.

Olson DM, Dinerstein E, Wikramanayake ED et al. (2001) Terrestrial ecoregions of the world: A new map of life on earth - A new global map of terrestrial ecoregions provides an innovative tool for conserving biodiversity. BioScience 51: 933-938.

Oslisly R, White L, Bentaleb I et al. (2013) Climatic and cultural changes in the west Congo Basin forests over the past 5000 years. Philosophical Transactions of the Royal Society of London, Series B: Biological Sciences 368: 20120304.

Pederson N, Hessl AE, Baatarbileg N et al. (2014) Pluvials, droughts, the Mongol Empire, and modern Mongolia. Proceedings of the National Academy of Sciences 111: 4375-4379.

Prance G (1982) Biological Diversification in the Tropics: Proceedings of the Fifth International Symposium of the Association for Tropical Biology. New York: Columbian University Press.

Rodrigues AD (2010) Linguistic reconstruction of elements of prehistoric Tupí culture. In: Carlin EB and Van de Kerke S (eds) Linguistics and Archaeology in the Americas: The Historization of Language and Society. Leiden: Brill Publishers, pp. 1-10.

Rodrigues AD and Cabral AS (2012) Tupían. In: Campbell $\mathrm{L}$ and Grondona V (eds) The Indigenous Languages of South America. Berlin; Boston, MA: Mouton de Gruyter, pp. $495-574$.
Rogge JH (2005) Fenômenos de fronteira: Um estudo das situações de contato entre os portadores das tradições cerâmicas pré-históricas no Rio Grande do Sul. Pesquisas Antropologia 62: $1-125$.

Rowe H, Dunbar R, Mucciarone D et al. (2002) Insolation, moisture balance and climate change on the South American Altiplano since the Last Glacial Maximum. Climatic Change 52: 175-199.

Santos EJM, da Silva ALS, Ewerton PD et al. (2015) Origins and demographic dynamics of Tupí expansion: A genetic tale. Boletim do Museu Paraense Emílio Goeldi. Ciências Humanas 10: 217-228.

Santos-Granero F (2009) Vital Enemies: Slavery, Predation, and the Amerindian Political Economy of Life. Austin, TX: University of Texas Press.

Scheel-Ybert R, Beauclair M and Buarque A (2014) The forest people: Landscape and firewood use in the Araruama region, southeastern Brazil, during the late-Holocene. Vegetation History and Archaeobotany 23: 97-111.

Scheel-Ybert R, Macario K, Buarque A et al. (2008) A new age to an old site: The earliest Tupiguarani settlement in Rio de Janeiro State? Anais da Academia Brasileira de Ciências 80: 763-770.

Schmidl U (1599 [1567]) Vera historia admirandae cuiusdam navigationis, quam Huldericus Schmidel Straubingensis ab Anno 1534 usque ad annum 1554 in Americam vel novum mundum, iuxta Brasiliam \& Rio della Plata, confecit. Noribergae: Impensis Levini Hulsii.

Schmitz PI (1991) Migrantes da Amazonia: A Tradicao Tupiguarani. In: Kern A (ed.) Arqueologia Prehistorica do Rio Grande do Sul. Porto Alegre: Mercado Aberto, pp. 295-330.

Silva LC, Sternberg L, Haridasan M et al. (2008) Expansion of gallery forests into central Brazilian savannas. Global Change Biology 14: 2108-2118.

Spracklen DV, Arnold SR and Taylor C (2012) Observations of increased tropical rainfall preceded by air passage over forests. Nature 489: 282-285.

Staden H (1557) Warhaftige Historia und beschreibung eyner Landtschafft der Wilden Nacketen, Grimmigen Menschfresser-Leuthen in der Newenwelt America gelegen. Marburg: Andreas Kolb.

Stevaux JC (2000) Climatic events during the late Pleistocene and Holocene in the upper Parana River: Correlation with NE Argentina and South-Central Brazil. Quaternary International 72: 73-85.

Van Geel B, Bokovenko N, Burova N et al. (2004) Climate change and the expansion of the Scythian culture after $850 \mathrm{BC}$ : A hypothesis. Journal of Archaeological Science 31: 1735-1742.

Viveiros de Castro EB (1992) From the Enemy's Point of View: Humanity and Divinity in an Amazonian Society. Chicago, IL: University of Chicago Press.

Walker RS, Wichmann S, Mailund T et al. (2012) Cultural phylogenetics of the Tupi language family in lowland South America. PLoS ONE 7: e35025.

Wang X, Auler AS, Edwards R et al. (2007) Millennial-scale precipitation changes in southern Brazil over the past 90,000 years. Geophysical Research Letters 34: L23701.

Whitney BS and Mayle FE (2012) Pediastrum species as potential indicators of lake-level change in tropical South America. Journal of Paleolimnology 47: 601-615.

Zech M, Zech R, Morrás H et al. (2009) Late Quaternary environmental changes in Misiones, subtropical NE Argentina, deduced from multi-proxy geochemical analyses in a palaeosolsediment sequence. Quaternary International 196: 121-136.

Zhou J and Lau K (1998) Does a monsoon climate exist over South America? Journal of Climate 11: 1020-1040. 